Organizational Market Information Processes: Cultural Antecedents and New Product

\title{
Outcomes
}

Author(s): Christine Moorman

Source: Journal of Marketing Research, Vol. 32, No. 3 (Aug., 1995), pp. 318-335

Published by: American Marketing Association

Stable URL: http://www.jstor.org/stable/3151984

Accessed: 23/09/2013 16:33

Your use of the JSTOR archive indicates your acceptance of the Terms \& Conditions of Use, available at

http://www.jstor.org/page/info/about/policies/terms.jsp

JSTOR is a not-for-profit service that helps scholars, researchers, and students discover, use, and build upon a wide range of content in a trusted digital archive. We use information technology and tools to increase productivity and facilitate new forms of scholarship. For more information about JSTOR, please contact support@jstor.org. 
Organizational research suggests that the way information is used is likely to $b \in$ a function of the presence of organizational systems or processes, in addition to individual manager activities. The author suggests that firms vary their emphasis on certain organizational market information processes, such as information acquisition, information transmission, conceptual use of information, and instrumental use of information. The author argues that the emphasis is determined, in part, by the congruence, or fit, among an organization's cultural norms and values and theorizes that the presence of these organizational information processes affects new product outcomes. Survey results indicate that clans dominate the other cultures in predicting organizational market information processes, suggesting that information processes are fundamentally "people processes" that involve commitment and trust among organizational members. The results have important implications for balancing internal and external orientations within firms. The results also indicate that the information utilization processes, especially those that are conceptual in nature, are strong predictors of new product performance, timeliness, and creativity, indicating that competitive advantage is tied to information utilization activities in firms.

\section{Organizational Market Information Processes: Cultural Antecedents and New Product Outcomes}

Marketing has historically addressed information processing and utilization from the perspective of the individual decision maker (Deshpandé and Zaltman 1982; Wilton and Myers 1986), often examining the effect of information on decision makers' performance (Glazer, Steckel, and Winer 1992; Glazer and Weiss 1993; Mahajan 1992; Perkins and Rao 1990). Marketing literature has also focused on the effects of organizational characteristics, such as structure and communication patterns on individual managers' use of information (Deshpandé and Zaltman 1982; Hutt, Reingen, and Ronchetto 1988; Menon and Varadarajan 1992; Mohr and Nevin 1990; Moorman, Deshpandé, and Zaltman 1993). Although such research has provided insight into information utilization and the various factors that influence it, the marketing literature has yet to fully examine the nature of

*Christine Moorman is Assistant Professor of Marketing, Graduate School of Business, University of Wisconsin, Madison. The author thanks George Day, Jan Heide, Anne Miner, J. Paul Peter, Aric Rindfleisch, Craig Thompson, UCLA, Wharton, and Queen's University Seminar Participants, and three anonymous reviewers for their constructive comments on an earlier version of this article. The author also appreciates the support of editors Bart Weitz and Vijay Mahajan. information processes as they occur at the organizational level. ${ }^{1}$

Organizational research has a long tradition of research suggesting that the way information is used is likely to be a function of the presence of organizational systems or processes, in addition to individual manager activities (Cyert and March 1992; Daft and Weick 1984; Weick 1979). This tradition argues that an organization's ability to process and learn from information extends beyond the capacity of individual organizational members (Hedberg 1981). Instead, this ability evolves over time and is expressed in an organization's information processes (Huber 1991), which may in-

1There are a few recent exceptions in the marketing literature. Kohli and Jaworski (1990) have conceptualized market orientation as involving a series of organizational information processes (see also Day 1991; Narver and Slater 1990; Sinkula 1994). It is unclear whether the work of Deshpandé and Zaltman (1982) is operating at the individual or organizational level. However, the positioning of their articles as involving the "use of specific market research information by marketing managers" (Deshpandé and Zaltman 1982, abstract), and their subsequent focus on comparing the use of information by researchers to that of managers (Deshpandé and Zaltman 1984) suggests they are operating at the individual level. Despite this, their information use scale could be used at either the individual or organizational level. 
clude processes for acquiring, disseminating, and utilizing information (Beyer and Trice 1982). Such processes have been viewed as "knowledge assets" (Winter 1987) that can be leveraged to achieve competitive advantage (Cohen and Levinthal 1990; Leonard-Barton 1991; Levitt and March 1988).

Despite potential contributions to the marketing literature, the organizational view of information processes is presently underutilized. My research attempts to address this deficiency by specifically resolving several issues that would increase the contribution of the organizational view to marketing. First, because no study has examined whether individual information processes are empirically distinct from organizational information processes, it is unclear whether these processes have been measured at the organizational level. Second, unlike previous research, which has tended to focus on a subset of organizational information processes, I attempt to explicate a more complete conceptual domain for these processes. Third, though research has focused on the structural antecedents of information use (Deshpandé and Zaltman 1982; Kohli and Jaworski 1990), previous research has failed to understand the cultural antecedents of organizational information processing in firms. Fourth, previous research has not provided empirical results regarding how organizational information processes affect marketing performance. The one exception, Jaworski and Kohli's (1993) study, examines several consequences of a firm's market orientation. However, they do not consider how the individual information processes within a firm's market orientation can have different performance outcomes. Moreover, Jaworski and Kohli's (1993) study and other conceptual work have been confined to assessing overall business performance, without regard to specific effects on new product performance, which previous research suggests is likely to be strongly influenced by the nature of firm-level information activities, including information acquisition (Day 1991, 1994; Dickson 1992), information transmission (Hutt, Reingen, and Ronchetto 1988; Imai, Nonaka, and Takeuchi 1985), and information utilization (Clark and Fujimoto 1991; Day 1994).

I address these gaps in the literature with three key objectives: (1) to conceive of a more complete set of organizational information processes and empirically distinguish them from individual information processing activities; (2) to examine cultural factors as antecedents of organizational information processes; and (3) to investigate the effects of these organizational information processes on several new product outcomes.

\section{ORGANIZATIONAL MARKET INFORMATION PROCESSES}

Glazer (1991, p. 2) defined market information as "data that have been organized or given structure - that is, placed in context-and endowed with meaning." I build on Glazer's definition by defining market information as data concerned with a firm's current and potential external stakeholders. Defined in this way, market information refers to external information that cuts across all functional areas of the firm rather than the more delimited "marketing information" that suggests it applies only to marketing departments. The sub- stantive content of market information is broad enough to include what is known as a result of experience and primary or secondary research studies. Moreover, information can arise from a variety of external sources (Barabba and Zaltman 1991; Kohli and Jaworski 1990).

The premise of my research is that the way an organization processes market information is likely to be a function of its organizational systems (Cyert and March 1992). As Hedberg $(1981$, p. 6$)$ notes:
Although organizational learning occurs through indi- viduals, it would be a mistake to conclude that organi- zational learning is nothing but the cumulative result of their members' learning. Organizations do not have brains, but they have cognitive systems and memories. As individuals develop their personalities, personal habits, and beliefs over time, organizations develop world views and ideologies. Members come and go, and leadership changes, but organizations' memories pre- serve certain behaviors, mental maps, norms, and val- ues over time.

This view argues that organizations contain information systems (Daft and Weick 1984; Sandelands and Stablein 1987; Weick 1979). These systems involve persons who create, disseminate, and act on shared meanings, but who are subordinate to the system and its corresponding processes that represent "collective ways of acting or thinking [that] have a reality outside of the individuals who ... conform to it" (Durkheim 1938, cited in Walsh 1989, p. 15). This is also consistent with the view that individual learning contributes to organizational learning, but is an insufficient condition for organizational learning (Argyris and Schön 1978; Sinkula 1994).

\section{Four Key Organizational Market Information Processes}

The extant literature has consistently conceptualized information activities as comprised of a series of processes. These views are found in literature concerned with adoption of innovations (Rogers 1983; Zaltman 1979; Zaltman, Duncan, and Holbek 1973); information processing models (Lavidge and Steiner 1961; Ray et al. 1973); information utilization activities (Deshpandé and Zaltman 1982, 1984; Menon and Varadarajan 1992); organizational learning (Day 1991, 1994; Fiol and Lyles 1985; Huber 1991; Levitt and March 1988); and the sociology of science (AMA Task Force 1988; Knorr-Cetina 1981). Drawing on these research streams, four organizational market information processes are envisioned, half of which contain subprocesses: (1) information acquisition; (2) information transmission; (3) conceptual utilization; and (4) instrumental utilization processes.

Information acquisition processes. These processes refer to the collection of primary or secondary information from organizational stakeholders. Information acquisition may occur, for example, through formal market research surveys, competitive intelligence activities, or customer satisfaction studies; through informal collection of information from salespeople who interact with customers; or from competitors who share information at industry association meetings. Information acquisition has been described as attention (Bettman 1979; Kahneman 1973) or awareness (Rogers 1983) that has direction and intensity. In various organizational literatures, information acquisition has also been 
termed intelligence generation (Kohli and Jaworski 1990), information search (Weiss and Heide 1993), and initiation (Zaltman, Duncan, and Holbek 1973). All this literature indicates that organizational information acquisition processes involve bringing information about the external environment into the boundary of the organization (Kiesler and Sproull 1982; Starbuck 1976; Weick 1969).

Information transmission processes. These processes refer to the degree to which information is diffused among relevant users within an organization (Beyer and Trice 1982; Glaser, Abelson, and Garrison 1983; Kohli and Jaworski 1990). Information transmission may occur formally or informally (Dickson 1994; Mohr and Nevin 1990). Formal transmission is any type of organized or structured dissemination, including policies, training sessions, research presentations, company memoranda, meetings, and cross-functional teams (Narver and Slater 1990). Informal transmission occurs during interpersonal interactions, such as casual conversations involving market information, or when organizational members educate one another on market issues. Transmission may be top-down, down-up, or horizontal (Day 1991; Kohli and Jaworski 1990).

Conceptual utilization processes. These processes refer to the indirect use of information in strategy-related actions (Menon and Varadarajan 1992; Rich 1981). Although the enactment of conceptual utilization processes often involves behaviors, the focus in these behaviors is on influencing the way organizations process information or their commitment to it, which are more cognitive and affective in nature and, therefore, more indirect in their influence on marketing strategies as compared with instrumental utilization (described subsequently). Two subprocesses are proposed.

First, information commitment refers to the extent to which an organization recognizes the value of information agents and products (Beyer and Trice 1982; Menon and Varadarajan 1992). It is revealed when an organization values information as an aid to decision making, as opposed to considering it a disruption (an informal process), whereas commitment to information providers may be found when information providers report to users at high organizational levels (a formal process).

Second, information processing refers to processes "through which information is given meaning" (Daft and Weick 1984, p. 294). Meaning is the result of "sensemaking" (Thomas, Clark, and Goia 1993), comprehending (Olson 1978), interpreting (Huber 1991), categorizing (Dutton and Jackson 1987; Jackson and Dutton 1988), or elaborating on evoked information using an organization's memory (Hedberg 1981; Levitt and March 1988), collective schema (Dunn and Ginsberg 1986; Houston 1993), or shared mental model (Day 1991; Day and Nedungadi 1994). This process is described by Dickson $(1994$, p. 46$)$ as the conversion of market intelligence "into knowledge and understanding when it is interpreted by, stored in, and changes the decision makers' mental models of the market environment." Information processing may involve formal procedures for organizing and processing information, such as analytical models or playing devil's advocate, or more informal processes, such as team meetings in which interpretations of market information are offered.
Instrumental utilization processes. These processes refer to the extent to which an organization directly applies market information to influence marketing strategy-related actions. Three subprocesses are investigated: the use of information in (1) making, (2) implementing, and (3) evaluating marketing decisions. Organizational use of information in decision making refers to processes involving the integration of information sources and the selection among strategy alternatives (for a discussion of these processes at the individual level, see Bettman, Johnson, and Payne 1991; Cohen, Miniard, and Dickson 1980). This type of information use has been historically reported to be very low (Weiss 1978). Thus, organizational research has suggested that decision making is not a distinct phase, but, rather, something that is "muddled through" (Mintzberg, Raisinghani, and Theoret 1976) or performed in a satisficing mode, which may limit information use.

Organizational use of information in implementation provides information about the enactment of marketing strategies to ensure the realization of decisions. This process follows other research showing that implementation is facilitated by providing information regarding how decisions should be carried out (Leonard-Barton and DeSchamps 1988; Nutt 1986; Slevin and Pinto 1987). In contrast, Jaworski and Kohli (1993) describe market responsiveness as involving issues of whether and how quickly the firm responds to market information in the design and implementation of marketing strategies.

Finally, organizational use of information in evaluation refers to processes for using market information to determine positive and negative performance outcomes and the reasons for these outcomes (Zaltman and Moorman 1989). In the diffusion of innovations literature, this is referred to as the confirmation stage, because the focus is on assessing the benefits of adoption (Rogers 1983). Evaluation, or performance feedback, has been described as being crucial to successful organizational adaptation (Fiol and Lyles 1985) and change (Argyris 1976). Therefore, organizations that use market information to evaluate outcomes are more likely to develop effective "theories of action" (Barabba and Zaltman 1991).

\section{CONCEPTUAL FRAMEWORK}

This section links the four organizational market information processes described in the previous section to certain new product outcomes and cultural antecedents.

\section{Cultural Antecedents of Organizational Market Information Processes}

Organizational culture is defined by Deshpandé and Webster $(1989$, p. 4) as "the pattern of shared values and beliefs that help individuals understand organizational functioning and that provide norms for behavior in the organization." Previous research indicates that organizational culture affects organizations in two ways. It can affect, first, the firm's choice of outcomes and, second, the means to achieve these outcomes, including organizational structure and processes (Cameron and Freeman 1991; Deshpandé, Farley, and Webster 1993; Hatch 1993; Quinn and Rohrbaugh 1983; Ruekert, Walker, and Roering 1985; Webster and Deshpandé 1990). 


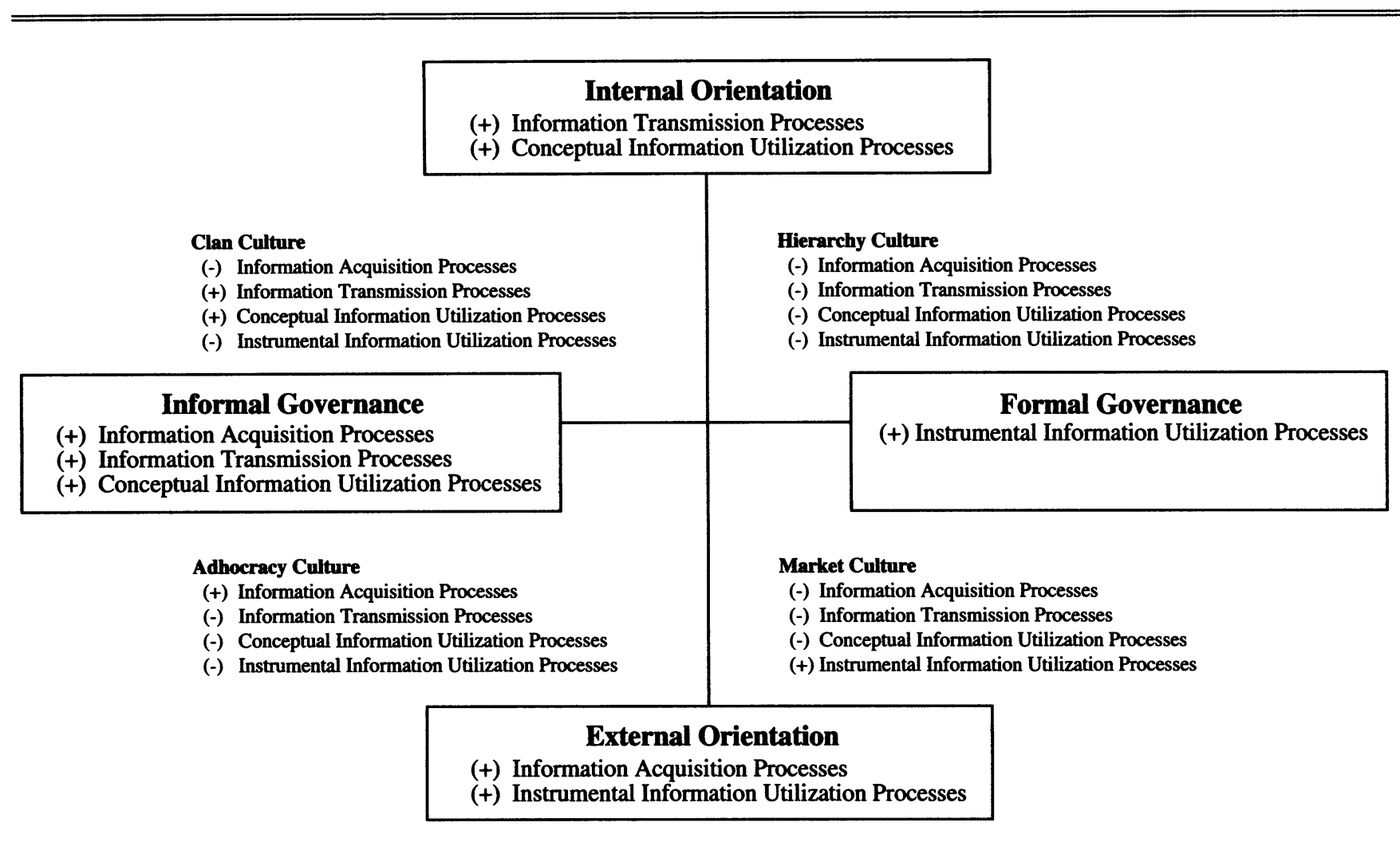

*(+) denotes that the culture emphasizes the information process.

$(-)$ denotes that the culture de-emphasizes the information process.

To understand the impact of culture on organizational information processes, the competing values model of culture is adopted (Deshpandé, Farley, and Webster 1993; Quinn 1988; Quinn and Rohrbaugh 1983). Briefly, the model proposes two predominant dimensions by which cultural values vary. These two axes form a four-cell model of culture. One axis, the informal-formal dimension, reflects preferences about the importance of organizational structure and involves a continuum from organic to mechanistic processes. The second axis, the internal-external dimension, describes whether the emphasis is on the maintenance of an organization's internal sociotechnical system or the improvement of its competitive position within the external environment. The four cultures resulting from the intersection of the two dimensions have been labeled adhocracies, markets, hierarchies, and clans. ${ }^{2}$ To determine how these four cultures in-

\footnotetext{
2Some researchers use similar terms to describe organizational governance modes. In marketing, these four archetypes have been used primarily by Deshpandé, Farley, and Webster (1993) and Deshpandé and Webster (1988), who have referred to them as organizational cultures. However, Ruekert, Walker, Roering (1985) refer to them as governance modes. In the organizational literature, there is an entire stream of literature called the competing values view that refers to these four types as organizational cultures (e.g., Quinn and Rohrbaugh 1983). Although other literature has discussed individual archetypes (see, for example, Mintzberg 1979; Ouchi 1980; Williamson 1981), it is my preference to remain most closely aligned with the work of Deshpandé and the competing values literature that views these four archetypes as organizational cultures.
}

fluence the emphasis placed on various organizational market information processes, I describe the focus of each end of the two axes and then discuss how the intersection of these axes produces an emphasis on certain information processes. Figure 1 depicts the proposed view.

Externally-focused cultures versus internally-focused cultures. Externally-focused cultures will have better developed information acquisition and instrumental utilization processes, both of which involve interaction with the external environment. Information acquisition processes involve environmental scanning and intelligence activities and the importation of the resulting information into the organization. Instrumental utilization processes entail the design and implementation of marketing actions that influence external constituencies.

Internally-focused cultures, on the other hand, have more well-developed information transmission and conceptual utilization processes, both of which function completely internal to the organization. Information transmission processes involve dissemination of information among organizational members, whereas conceptual utilization processes emphasize increasing members' understanding of and commitment to acquired information.

Formal cultures versus informal cultures. In general, formalization has been found to reduce the level of information utilization in firms (Deshpandé 1982; Deshpandé and Zaltman 1982). Offering a contrasting view, Zaltman, Duncan, 
and Holbek (1973) make a finer distinction: Formalization may have opposite effects on different types of innovative behavior, among which information processes may be included (Zaltman 1979). Specifically, Zaltman, Duncan, and Holbek (1973) suggest that formalized organizations may interfere with the initiation stages of the adoption process (e.g., acquiring, understanding, becoming committed to an innovation), but facilitate the implementation stages of the adoption process (see also John and Martin 1984; Kohli and Jaworski 1990). Previous research has generally not identified such findings because it has failed to distinguish between different types of information utilization. ${ }^{3}$

Accordingly, it is argued that formalized cultures will facilitate instrumental utilization processes because these processes involve using information to take marketing actions, while reducing information acquisition, information transmission, and conceptual utilization processes. If formal cultures reduce these processes, then logically it is inferred that informal cultures should foster information acquisition, information transmission, and conceptual utilization processes while also reducing instrumental utilization processes. Other research supports this view by suggesting that informal organizations facilitate information acquisition (Imai, Nonaka, and Takeuchi 1985; Zaltman 1979), information transmission (Imai, Nonaka, and Takeuchi 1985; Menon and Varadarajan 1992), and conceptual utilization (by weakening myopic interpretations, see Day 1991).

A four cell model of organizational market information processes. By combining the two previously described axes to form a four-cell model of different cultures, it is possible to determine the degree to which each culture tends to emphasize or de-emphasize certain organizational market information processes. In making these determinations, a congruence approach is adopted, which focuses on the degree to which the organization's cultural values are mutually supportive of a firm's processes. When cultural values are aligned in this way, previous research suggests that corresponding organizational processes are more likely to be present and effective than when cultural values are not congruent (Cameron and Freeman 1991; Deal and Kennedy 1982; Nadler and Tushman 1980; Quinn and Rohrbaugh 1983; Ruekert, Walker, and Roering 1985; Williamson and Ouchi 1981).

To implement the congruence approach, the two bordering axes for each cell in the previously described competing values framework are examined. As Figure 1 depicts, when the two axes indicate that similar information processes should occur, the organization should emphasize these processes. However, when the value axes do not overlap and are, therefore, not mutually supportive of certain information processes, it is hypothesized that the information processes will be de-emphasized. I describe each culture and note its focus on certain organizational information processes. Then, I offer a set of formal propositions.

3The one exception, Jaworski and Kohli's (1993) study, failed to find dif ferent effects for indicators of hierarchy on organizational design responsiveness and organizational implementation responsiveness. This may have been, in part, because implementation responsiveness focused more on timeliness of responses than the use of information in implementation.
Adhocracies value both flexibility and their competitive position in the external environment (Deshpandé, Farley, and Webster 1993). Hence, they tend to emphasize entrepreneurship, creativity, and adaptability (Mintzberg 1979). An adhocracy's value orientation supports only the presence of organizational information acquisition processes. Consistent with this view, Quinn (1988) notes that adhocracies tend to be effective at acquiring resources and performing boundary spanning functions (see also Cameron and Freeman 1991); Quinn and Rohrbaugh (1983) suggest that adhocracies tend to acquire information about the environment while emphasizing no other information processes; and Slater and Narver (1994) note that entrepreneurial cultures such as adhocracies thrive on information acquisition (see Zammuto and Krakower 1991). Thus, organizational information acquisition processes should be strong in adhocracies, though the other information processes should be weak or nonexistent.

Markets emphasize goal achievement, productivity, and efficiency (Cameron and Freeman 1991; Deshpandé, Farley, and Webster 1993), reflecting their external orientation and value for formal governance systems. These values support the presence of instrumental utilization processes without supporting any other information process. Instrumental utilization processes are consistent with markets' values because they involve using information to influence a firm's effectiveness in the environment (Denison and Spreitzer 1991). Moreover, the norms characteristic of marketsnorms that reward actions such as planning, objective setting, and evaluation (Quinn and Rohrbaugh 1983) - reflect the nature of instrumental utilization processes well. Therefore, organizational instrumental utilization processes should be promoted within market cultures, whereas the other information processes should be weak or nonexistent.

Hierarchies emphasize order, uniformity, efficiency, certainty, stability, and control, reflecting internally oriented and formalized values (Deshpandé, Farley, and Webster 1993). The information processes supported by these value axes fail to overlap one another, suggesting that none of the information processes will be supported (see Figure 1; Quinn and Spreitzer 1991). Consistent with this, Lovell and Turner (1988, p. 414) suggest that hierarchies tend to force a form of localized information use on the organization by requiring that "subunits handle pieces of the organization's problems in relative independence." Likewise, hierarchies are less likely to develop the person-to-person systems crucial to information processes (Patton 1978). Some research does suggest that hierarchies are effective in the management and communication of information (Cameron and Freeman 1991; Quinn and Rohrbaugh 1983). However, other research has documented that hierarchies do not support organizational information transmission (Deshpandé and Kohli 1989; Jaworski and Kohli 1993).

Clans stress participation, teamwork, and cohesiveness (Ouchi 1980). The emphasis is on the development of shared organizational understanding and commitment through participative, as opposed to centralized, communication processes (Quinn 1988; Quinn and Rohrbaugh 1983). Clan cultures have been found to be high in trust, low in conflict, and low in resistance to change (Zammuto and Krakower 1991). 
Figure 1 indicates that information transmission processes and conceptual utilization processes are mutually supported in this culture. In support of this, Moorman, Zaltman, and Deshpandé (1992) report that trust between information providers and users increases the amount of information shared between parties. Acquisition processes and instrumental use processes, on the other hand, are focused on the external environment, which suggests they will not be emphasized in clans' internally-focused cultures.

Predictions. From Figure 1, it is possible to predict which cultures will have stronger information processes relative to the others. For example, adhocracies are the only culture indicated to have strong information acquisition processes; clans are the only to have strong information transmission and conceptual utilization processes; and markets are the only to have strong information utilization processes. Therefore:

$\mathrm{H}_{1}$ : Adhocracy cultures will have stronger organizational information acquisition processes than market, hierarchy, and clan cultures.

$\mathrm{H}_{2}$ : Clan cultures will have stronger organizational information transmission processes than adhocracy, market, and hierarchy cultures.

$\mathrm{H}_{3}$ : Clan cultures will have stronger organizational conceptual utilization processes than adhocracy, market, and hierarchy cultures.

$\mathrm{H}_{4}$ : Market cultures will have stronger organizational instrumental utilization processes than adhocracy, hierarchy, and clan cultures.

\section{The Effects of Organizational Market Information \\ Processes on New Products}

This section explores how organizational market information processes influence the success of new products. A central assumption here is that organizational information processes mediate the direct relationship between culture and new product outcomes. This assumption, though not formally examined, is supported by a great deal of literature suggesting that cultures give rise to organizational structures and processes (Cameron and Freeman 1991; Quinn and Rohrbaugh 1983; Reukert, Walker, and Roering 1985; Webster and Deshpandé 1990). These processes, in turn, affect the nature and effectiveness of marketing strategies and outcomes.

New products were selected as the focal marketing outcome for several reasons. First, new product development and the success of new products has emerged as one of the critical strategic concerns of firms in the last decade (Marketing Science Institute 1994). Second, prior research has indicated that new product strategies are likely to be influenced by a range of firm information systems and processes. Specifically, Clark and Fujimoto (1991) characterize new product development processes as "total information systems" that are driven by firm-level processes; Day (1994) suggests that various market sensing information processes are crucial inputs to new product activities in learning firms (see also Dickson 1992); Imai, Nonaka, and Takeuchi (1985), Griffin and Hauser (1992), and Hutt, Reingen, and Ronchetto (1988) find that effective new product development processes involve continuous information sharing and utilization. Accordingly, the new product domain seems particularly well suited to examining the impact of organizational information processes. Three new product outcomes are examined: performance, timeliness, and creativity.

New product performance is the degree to which organizational goals involving new product profit, sales, and share have been reached. As justification for the effect of the market information processes on performance, Jaworski and Kohli (1993) provide evidence that market orientation, which reflects several information processes, has a positive influence on overall firm performance. Considering the effect of each organizational information process on new product performance, information acquisition processes should lead to greater performance because they assist in the identification of market opportunities and threats that may facilitate effective strategy development (Fahey and Naraynan 1986). Information transmission may also improve performance because it is likely to increase the degree to which organizational members share a vision of marketing strategy design and implementation-something total quality management approaches and learning theories tout as important to effective firm action (Doughterty 1989; Imai, Nonaka, and Takeuchi 1985; Narver and Slater 1990; Senge 1990; Sinkula 1994). Conceptual utilization processes have the capacity to improve performance because they may have the effect of improving managers' thinking about marketing problems (Barabba and Zaltman 1991; Day and Nedungadi 1994; Menon and Varadarajan 1992). Finally, instrumental utilization processes affect new product performance by influencing the effectiveness of decision making and implementation (Glazer 1991; Porter and Millar 1985; Nelson 1982). Thus:

$\mathrm{H}_{5}$ : The greater the organizational (a) information acquisition processes, (b) information transmission processes, (c) conceptual utilization processes, and (d) instrumental utilization processes, the greater the new product performance.

New product timeliness is the extent to which new products are introduced during environmental conditions that promote their success (Fahey and Naraynan 1986). Previous research suggests that how organizational information processes affect timeliness depends on which information process is being considered. Information acquisition processes, for example, are critical in sensing signals of environmental change (Klein and Newman 1980) and, thus, allow organizations to generate timely strategies. Likewise, effective information transmission should speed the process of strategy development because it ensures that all parties involved are aware of relevant information that is crucial to the new product (Cooper and Kleinschmidt 1994). In fact, effective transmission serves the same purpose as other steps firms take to speed up new product development, including overlapping product development stages and multifunctional teams (Clark and Fujimoto 1991; Nonaka 1990).

On the other hand, both conceptual utilization processes and instrumental utilization processes are expected to increase the time associated with new product activities because they require more time to enact. The information processing component of conceptual utilization, for example, requires time for managers to think about information, question key assumptions about markets, theorize about the ef- 
fectiveness of alternative approaches, and challenge one anothers' ideas (Rich 1981). Speeding up these processes, that is, causing "accelerated cognitive processing" (Eisenhardt 1989), would reduce the time associated with conceptual utilization. Likewise, the commitment component of conceptual use also requires time for managers to gain an appreciation for market information (Barabba and Zaltman 1991) and its providers (Moorman, Zaltman, and Deshpandé 1992). Finally, because instrumental utilization involves several stages typically associated with effective planningdecision making, implementation, and evaluation-it is also likely to require time to occur. In fact, it is because of the longer time horizons associated with planning that firms experiment with "compression strategies" (Tabrizi and Eisenhardt 1995) and "improvisation strategies" (Moorman and Miner 1995; Weick 1993a, b) to speed product development. Hence:

$\mathrm{H}_{6}$ : The greater the organizational (a) information acquisition processes or (b) information transmission processes and the weaker the organizational (c) conceptual utilization processes or (d) instrumental utilization processes, the greater the new product timeliness.

The final outcome, new product creativity, is the degree to which a new product is novel and its introduction changes marketing thinking and practice (Andrews 1992; Wilton and Myers 1986; Zaltman, Heffring, and LeMasters 1983). Strategic management theory suggests that successful organizations rely on information to detect opportunities emerging in the environment and respond with creative solutions (Aguilar 1967; Fahey and Naraynan 1986). On the other hand, information may actually interfere with creativity, because it inhibits organizations' abilities to generate solutions other than those that are dictated in the information (often referred to as "myopic interpretations," Day 1991; Dickson 1992; Levitt 1960). This latter position, however, does not account for the fact that certain information processes may actually mitigate these adverse effects on creativity. For example, organizational conceptual utilization processes may encourage decision makers to disagree and challenge one another's opinions. In fact, conceptual utilization processes tend to promote thinking about market information-one of the key inputs for creative outcomes. Because of the lack of prior literature, it is unclear how the remaining information processes will influence new product creativity, because they are not necessarily likely to foster or detract from divergent thinking. Therefore, no relationships for these information processes are hypothesized, but their effects are explored in the data analysis.

$\mathrm{H}_{7}$ : The greater the organizational conceptual utilization processes, the greater the new product creativity.

\section{METHOD}

\section{Sample and Procedure}

The initial sample consisted of 396 divisions of firms noted in the 1992 Advertising Age list of top 200 advertis- ers. ${ }^{4}$ Vice presidents of marketing were used as informants because of their knowledge of the firm, familiarity with its environment, and access to strategic and financial information (Aguilar 1967).

Informants were mailed a questionnaire and a cover letter that explained the purpose of the research and promised a summary of the results if they returned their business cards with the completed questionnaire. Informants were asked to focus on their most recent product development project that had been in the market for a minimum of 12 months for which their division was responsible. All questions regarding the organization, then, focused on the division as the organizational unit of analysis.

Three weeks following the first mailing, nonrespondents were telephoned, reminded of the questionnaire, and encouraged to complete and return it. Two weeks following the calls, a second mailing was sent to nonrespondents. Using a chi-square difference test, it was determined that for a subset of variables, there were no systematic differences between those who responded before and those who responded after the second mailing (Armstrong and Overton 1977)..$^{5}$ After eliminating persons who indicated that the questionnaire was inappropriate for their organization or experience, the overall sample was reduced from 396 to 300 . Of the eligible sample, $92(31 \%)$ responded.

\section{Measurement}

The Appendix contains all the measures, as well as their sources. Some measures were drawn from extant research. For others, it was necessary to create new measurement items specifically for this project. 6

After the data were collected, measures were subjected to a purification process (see Churchill 1979; Gerbing and Anderson 1988). The unidimensionality of each measure was assessed in a series of two-factor models in LISREL VII (Jöreskog and Sorbom 1989). The pairs of measures, which were selected from theoretically-similar subsets consisting of the four organizational market information processes, four organizational cultures, and three new product outcomes, allowed for the joint examination of maximally sim-

\footnotetext{
${ }^{4}$ Although the sample was drawn from the top 200 advertisers, it appears generalizable to organizations not involved in marketing consumer products. This is indicated by a measure asking informants to note whether their businesses include services, durables, nondurables, and industrial products. The results suggest that the subsequent percentages of informant business units are involved in these lines of business: services $(25 \%)$, durables $(27 \%)$, nondurables $(54 \%)$, and industrial $(32 \%)$. These percentages reflect the number of firms who noted that they worked in this business area (they were allowed to note more than one category) divided by the total number of business units in the sample $(n=92)$.

5 The results of these tests are $(E R=$ early responders and $L R=$ late responders): information acquisition processes $\left(E R=4.76, L R=4.65, \mathrm{t}_{(91)}=\right.$ $.44)$, information transmission processes $\left(E R=5.43, L R=5.41, t_{(91)}=.11\right)$, conceptual information use $\left(E R=5.48, L R=5.48, t_{(91)}=.01\right)$, instrumental information use $\left(E R=5.33, L R=5.26, t_{(91)}=.35\right)$, clan culture $(E R=$ $\left.4.08, \mathrm{LR}=3.99, \mathrm{t}_{(91)}=.24\right)$, and new product performance $(\mathrm{ER}=4.94, \mathrm{LR}$ $\left.=4.69, \mathrm{t}_{(91)}=.70\right)$. Other measures follow the same pattern, but are not reported here.

6All measures, except for those relating to culture, utilized their original scales. The culture measures were applied to a 7-point Likert scale to make the questionnaire easier to complete and decrease the dependence among measures created by the summated scale approach used in previous research.
} 
ilar constructs. This approach was chosen instead of a single model or models at the subset level to fit the constraints of confirmatory factor models, which do not provide good estimates on models that exceed a 5-to-1 ratio of sample size to parameter estimates (Bentler and Cho 1988). After the elimination of items that had very weak loadings or loaded on more than one factor, all remaining factor loadings were significant $(t>2.00)$ (Anderson 1987). ${ }^{7}$ Next, the reliability of each measure was assessed by calculating coefficient alpha. Item-to-total correlations were also inspected, and items with particularly low correlations were eliminated if doing so did not diminish the measure's coverage of the construct domain.

The next set of analyses was conducted to assess the discriminant validity of the subsets of measures (described previously) using a procedure recommended by Bagozzi and Phillips (1982) and Anderson (1987). Within each subset, pairs of constructs were assessed in a series of two-factor confirmatory factor models using LISREL VII. Each model was run twice-once constraining the correlation between the two latent variables to unity and once freeing this parameter. A chi-square difference test was then performed. For all of the models investigated, the chi-square values were significantly lower for the unconstrained models, which suggests the variables exhibit discriminant validity. 8

A final set of analyses was conducted to ensure that the organizational information process measures could be discriminated from a measure of individual use of information. Each of the four organizational information processes was paired with the individual use of market information measure in a series of two-factor models using LISREL VII. Each model was run twice, once constraining the correlation between the two latent variables to unity and once freeing this parameter. The results indicated that the chi-square values were significantly lower for the unconstrained models, which suggests the organizational and individual pro-

\footnotetext{
7In the interests of space, the factor loadings are not included in the article; however, they are available from the author.

8The critical value $\left(\Delta \chi^{2}{ }_{(1)}>3.84\right)$ was exceeded in all tests. The results include (where $\mathrm{U}$ is the unconstrained and $\mathrm{C}$ is the constrained estimate): acquisition and transmission processes $\left.\left(U_{[\mathrm{df}}=43\right]=99.42, C_{[\mathrm{df}}=44\right]=$ 115.43, $\left.\Delta \mathrm{X}^{2}(1)=16.01\right)$, acquisition and conceptual use processes $\left(\mathrm{U}_{[\mathrm{df}}=76\right]$ $\left.=172.56, \mathrm{C}_{[\mathrm{df}=77]}=179.33, \Delta \chi^{2}(1)=6.77\right)$, acquisition and instrumental use processes $\left(U_{[\mathrm{df}=134]}=281.53, C_{[\mathrm{df}=135]}=294.25, \Delta \chi^{2}{ }_{(1)}=12.72\right)$, transmission and conceptual use processes $\left(U_{[d f=89]}=193.12, C_{[d f=90]}=\right.$ $\left.198.51, \Delta \chi^{2}(1)=5.39\right)$, transmission and instrumental use processes $\left(U_{\text {[df }}=\right.$ $\left.151]=313.32, \mathrm{C}_{[\mathrm{df}=152]}=319.27, \Delta \chi^{2}(1)=5.95\right)$, conceptual use and instrumental use processes $\left.\left(U_{[\mathrm{df}}=208\right]=397.72, C_{[\mathrm{df}}=209\right]=401.62, \Delta \chi^{2}{ }^{2}(1)=$ 3.90), adhocracies and markets $\left.\left(U_{[\mathrm{df}}=13\right]=30.33, C_{[\mathrm{df}}=14\right]=35.79, \Delta \chi^{2}(1)$ $=5.46)$, adhocracies and hierarchies $\left(U_{[\mathrm{df}=13]}=30.58, C_{[\mathrm{df}=14]}=45.80\right.$, $\left.\Delta \chi^{2}{ }_{(1)}=15.22\right)$, adhocracies and clans $\left(U_{[d f=19]}=33.06, C_{[\mathrm{df}}=20\right]=50.31$, $\left.\Delta \chi^{2}(1)=17.25\right)$, markets and hierarchies $\left(U_{[d f=19]}=66.14, C_{[d f}=20\right]=$ 76.67, $\left.\Delta \chi^{2}(1)=10.53\right)$, markets and clans $\left(U_{[\mathrm{df}=19]}=36.53, \mathrm{C}_{[\mathrm{df}=20]}=\right.$ $\left.41.57, \Delta \chi^{2}(1)=5.04\right)$, new product performance and new product creativity $\left.\left.\left(U_{[\mathrm{df}}=53\right]=134.34, C_{[\mathrm{df}}=54\right]=145.16, \Delta \chi^{2}{ }_{(1)}=10.82\right)$, and new product creativity and new product timeliness $\left.\left(U_{[\mathrm{df}}=34\right]=76.50, C_{[\mathrm{df}}=35\right]=93.24$, $\left.\Delta \chi^{2}(1)=16.74\right)$.
}

cesses exhibit discriminant validity. ${ }^{9}$ Table 1 contains a correlation matrix of all measures, whereas Table 2 contains their psychometric information.

\section{General Theory Testing Approach}

The hypotheses were examined in seven regression models with the four organizational information processes and the three new product outcomes as dependent variables. Follow-up analyses were performed to determine the relative importance of the cultures to the organizational information processes. Environmental turbulence was entered as a control variable in the models predicting new product outcomes because of previous research's suggestion that it might influence performance. For all seven models, variance inflation factors were estimated to examine collinearity levels. The results were found to be below harmful levels (Mason and Perreault 1991). Table 3 contains the results of the analyses.

\section{RESULTS}

The most rigorous approach for determining which cultures are more predictive of the organizational information processes is to perform partial F-tests on the beta coefficients associated with pairs of the cultural predictors (Draper and Smith 1981; Neter and Wasserman 1974). Using this approach, one significant difference between cultures was found-that between clans and hierarchies in their effect on conceptual utilization processes $\left(\mathrm{F}_{(1)}=8.38, p<.001\right)$, which supports $\mathrm{H}_{3 \mathrm{~d}}$. None of the other parts of the first three hypotheses is supported. However, because of the small sample size and low power associated with these tests, as well as the lack of prior empirical research in this area, an alternative approach was explored (Pedhazur 1982, p. 64). It involved examining the relative size of the significant standardized beta coefficients (associated with the cultures). The subsequent discussion of $\mathrm{H}_{1}$ through $\mathrm{H}_{4}$ adopts this approach.

$H_{1}$ predicted that adhocracies would encourage information acquisition processes more than the other cultures. The results indicate that none of the cultures are significantly related to information acquisition; therefore, their relative effects cannot be determined. These results do not support $\mathrm{H}_{1}$ (see Table 3 ). $\mathrm{H}_{2}$ predicted that clans would facilitate the presence of information transmission processes more than the other cultures. The results suggest that clans $(\beta=.148)$ have the strongest positive effect on transmission processes (adhocracies $[\beta=.036]$, markets $[\beta=.005]$, and hierarchies $[\beta=-.005]$ ), which supports $\mathrm{H}_{2} \cdot \mathrm{H}_{3}$ suggested that clans would dominate in promoting conceptual utilization processes. The results support this hypothesis by indicating that clans have the strongest positive effect on conceptual use processes: clans $(\beta=.164)$, markets $(\beta=.128)$, adhocracies $(\beta=.086)$, and hierarchies $(\beta=-.195)$. Finally, $H_{4}$ predict-

\footnotetext{
9The critical value $\left(\Delta \chi^{2}{ }_{(1)}>3.84\right)$ was exceeded in all tests. The results include: organizational acquisition processes and individual use $\left(\mathrm{U}_{[\mathrm{df}}=89\right]$ $\left.=127.09, C_{[\mathrm{df}=90]}=161.52, \Delta \chi^{2}(1)=34.43\right)$, organizational transmission processes and individual use $\left.\left(\mathrm{U}_{[\mathrm{df}}=103\right]=150.32, \mathrm{C}_{[\mathrm{df}}=104\right]=192.90$, $\left.\Delta \chi^{2}(1)=42.58\right)$, organizational conceptual utilization processes and individual use $\left(U_{[d f=151]}=223.03, C_{[d f=152]}=246.57, \Delta x^{2}(1)=23.54\right)$, and organizational instrumental utilization processes and individual use $\left(\mathrm{U}_{[\mathrm{df}}=\right.$ $\left.{ }_{229]}=383.28, C_{[\mathrm{df}=230]}=416.66, \Delta \chi^{2}(1)=33.38\right)$.
} 
Table 1

CORRELATION MATRIX OF MEASURES*

\begin{tabular}{|c|c|c|c|c|c|c|c|c|c|c|c|c|c|}
\hline & & 1 & 2 & 3 & 4 & 5 & 6 & 7 & 8 & 9 & 10 & 11 & 12 \\
\hline (1) & Information Acquisition & & & & & & & & & & & & \\
\hline (2) & Information Transmission & .25 & & & & & & & & & & & \\
\hline (3) & Conceptual Utilization & .35 & .56 & & & & & & & & & & \\
\hline (4) & Instrumental Utilization & .42 & .68 & .66 & & & & & & & & & \\
\hline (5) & Adhocracy Culture & .05 & .04 & .07 & -.01 & & & & & & & & \\
\hline (6) & Market Culture & .14 & .23 & .42 & .32 & -.11 & & & & & & & \\
\hline (7) & Hierarchy Culture & .05 & .12 & .14 & .04 & .02 & .16 & & & & & & \\
\hline (9) & New Product Performance & .03 & .19 & .32 & .30 & .03 & .19 & -.15 & .06 & & & & \\
\hline (10) & New Product Timeliness & .06 & .10 & .30 & .27 & -.17 & .17 & -.08 & .04 & .44 & & & \\
\hline (11) & New Product Creativity & .20 & .09 & .33 & .21 & -.05 & .27 & .17 & .21 & .16 & .47 & & \\
\hline (12) & Individual Information Use & .17 & .14 & .41 & .29 & .18 & .18 & .04 & .28 & -.01 & .22 & .05 & \\
\hline (13) & Environmental Turbulence & .03 & .15 & .14 & .16 & .01 & .16 & .00 & .16 & .02 & -.15 & -.02 & .13 \\
\hline
\end{tabular}

*Correlations above $\rho=.23$ are significant at $p<.05$.

Table 2

PROPERTIES OF PURIFIED MEASURES

\begin{tabular}{|c|c|c|c|c|c|}
\hline Measure & Items & Range & Mean & Standard deviation & Alpha \\
\hline \multicolumn{6}{|c|}{ Organizational Market Information Processes } \\
\hline Information Acquisition Processes & 5 & $1-7$ & 4.73 & 1.10 & .65 \\
\hline Information Transmission Processes & 6 & $1-7$ & 5.42 & .86 & .70 \\
\hline Conceptual Utilization Processes & 9 & $1-7$ & 5.43 & .86 & .80 \\
\hline Instrumental Utilization Processes & 13 & $1-7$ & 5.31 & .92 & .91 \\
\hline \multicolumn{6}{|l|}{ Organizational Cultures } \\
\hline Adhocracy Culture & 4 & $1-7$ & 4.43 & 1.21 & .57 \\
\hline Market Culture & 4 & $1-7$ & 4.30 & 1.62 & .81 \\
\hline Hierarchy Culture & 3 & $1-7$ & 3.67 & 1.41 & .57 \\
\hline Clan Culture & 4 & $1-7$ & 4.05 & 1.75 & .85 \\
\hline \multicolumn{6}{|l|}{ New Product Outcomesa } \\
\hline New Product Performance & 5 & $1-7$ & 4.86 & 1.49 & .95 \\
\hline New Product Timeliness & 3 & $1-7$ & 5.26 & 1.42 & .92 \\
\hline New Product Creativity & 7 & $1-7$ & 5.22 & 1.14 & .85 \\
\hline \multicolumn{6}{|l|}{ Discriminating and Control Variables } \\
\hline Environmental Turbulence & 6 & $1-7$ & 4.62 & 1.34 & .84 \\
\hline
\end{tabular}

aThese measures were assessed with regard to a new product that had been in the market for at least 12 months.

ed that markets would promote instrumental utilization processes to a greater extent than the other cultures. The results do not support these relationships because clans $(\beta=.162)$ were again the strongest predictor, followed by markets $(\beta=$ $.061)$, adhocracies $(\beta=.010)$, and hierarchies $(\beta=-.067)$.

Turning to the effect of the information processes on the new product outcomes, $\mathrm{H}_{5}$ theorized that all of the information processes would have a significant positive effect on the performance of new products. The results indicate that information acquisition $(\beta=-.188)$ and information transmission $(\beta=-.151)$ are not related, thus, failing to support $\mathrm{H}_{5 \mathrm{a}-\mathrm{b}}$. However, both conceptual utilization $(\beta=.418)$ and instrumental utilization $(\beta=.419)$ had significant positive effects on the performance of new products, which supports $\mathrm{H}_{5 \mathrm{c}-\mathrm{d}}$. The control variable, environmental turbulence, is not related to performance $(\beta=-.039$; see Table 4$)$.

$\mathrm{H}_{6}$ theorized that information acquisition and information transmission would be positively related, and conceptual utilization and instrumental utilization would be negatively related to new product timeliness. The results indicate oth- erwise. Specifically, acquisition processes $(\beta=-.122)$ and transmission processes $(\beta=-.348)$ are not related to new product timeliness, whereas conceptual utilization $(\beta=$ $.432)$ and instrumental utilization $(\beta=.444)$ are positively related to timeliness. As previously, environmental turbulence has no relationship with timeliness $(\beta=-.074)$.

$\mathrm{H}_{7}$ theorized that conceptual utilization would be positively related to new product creativity. The results support this hypothesis $(\beta=.487)$. None of the effects of the remaining information processes were found to be related to new product creativity: acquisition $(\beta=.093)$, transmission $(\beta=-.218)$, and instrumental utilization $(\beta=.080)$. Finally, the control variable, environmental turbulence, had a significant negative relationship with new product creativity $(\beta=$ $-.168)$.

\section{DISCUSSION}

\section{The Organizational Market Information Processes}

The conceptualization and measurement of organizational market information processes presented here offers a 
number of advantages over existing approaches. First, the conceptualization is interdisciplinary, containing ideas from marketing, organizational, diffusion of innovation, knowledge utilization, and information processing theories. Second, the conceptualization is more comprehensive than is found currently in the marketing literature on organizational learning (Day 1991, 1994), organizational information processing (Sinkula 1994), and market orientation (Kohli and Jaworski 1990), which does not include all of the proposed processes and subprocesses. Third, the conceptualization is at the organizational level, and measures of the organizational information processes are empirically discriminated from measures of individual information processes.

Conceiving of and measuring various organizational information processes offers a number of important advantages to marketing research. This approach, for example, indicates the role that organizational-level processes might play in research that has tended to have an individual-level focus. In fact, one potentially useful direction for further research would be to investigate the relative effectiveness of individual-level and organizational-level information processes on various firm outcomes. In this way, the recent work of Glazer and Weiss (1993) could be extended by examining whether the tendency to underweight time-sensitive information in planning (an instrumental utilization process) is greater at the organizational level in which group-level processes might be expected to diffuse individual responsibility for decision-making outcomes (than at the individual level). Investigating organizational information processes also opens up new research avenues, such as understanding how these processes are related to organizational learning and organizational memory (Day 1991, 1994; Levitt and March 1988; Sinkula 1994). Finally, researchers may wish to examine the effectiveness of these organizational market information process measures relative to other published scales, such as market orientation (Kohli, Jaworski, and Kumar 1993).

\section{Cultural Antecedents of Organizational Market Information Processes}

It was surprising to find that the congruence of cultural factors was less important for predicting the presence of organizational information processes than the degree to which the culture was a clan. However, the present study is the first to investigate empirically the presence of informational processes in firms as a function of culture. Therefore, the findings extend prior research in important ways.

Table 3

STANDARDIZED ESTIMATES OF THE EFFECTS OF ORGANIZATIONAL CULTURE ON ORGANIZATIONAL MARKET INFORMATION PROCESSES $\left(\mathrm{H}_{1}-\mathrm{H}_{4}\right)$

\begin{tabular}{|c|c|c|c|c|}
\hline & $\begin{array}{c}\text { Information } \\
\text { Acquisition } \\
\text { Processes }\end{array}$ & $\begin{array}{c}\text { Information } \\
\text { Transmission } \\
\text { Processes }\end{array}$ & $\begin{array}{l}\text { Conceptual } \\
\text { Utilization } \\
\text { Processes }\end{array}$ & $\begin{array}{c}\text { Instrumental } \\
\text { Utilization } \\
\text { Processes }\end{array}$ \\
\hline Adhocracy Culture & $.054 \quad(.569)$ & $.036 \quad(.500)$ & $.086 \quad(1.285)$ & $(.142)$ \\
\hline Market Culture & $-.011(-.101)$ & $(.056)$ & $.128 \quad(1.606)$ & (.673) \\
\hline Hierarchy Culture & $-.030(-.328)$ & $-.005 \quad(-.073)$ & $-.195 *(-3.004)$ & $(-.917)$ \\
\hline Clan Culture & $.139(1.215)$ & $.148 * *(1.699)$ & $.164 *(2.052)$ & $.162 * *(1.775)$ \\
\hline $\begin{array}{l}\mathrm{R}^{2} \\
\text { F-statistic }(n=92, \mathrm{df}=[4,88])\end{array}$ & $\begin{array}{l}.041 \\
.938\end{array}$ & $\begin{array}{c}.094 \\
2.292 * *\end{array}$ & $\begin{array}{c}.273 \\
8.254^{*}\end{array}$ & $\begin{array}{l}.137 \\
3.501 *\end{array}$ \\
\hline
\end{tabular}

Note: $t$-values are in parenthesis.

${ }^{*} p<.05$

$* * p<.10$

Table 4

STANDARDIZED ESTIMATES OF THE EFFECTS OF ORGANIZATIONAL MARKET INFORMATION PROCESSES ON NEW PRODUCT OUTCOMES $\left(\mathrm{H}_{5}-\mathrm{H}_{7}\right)$

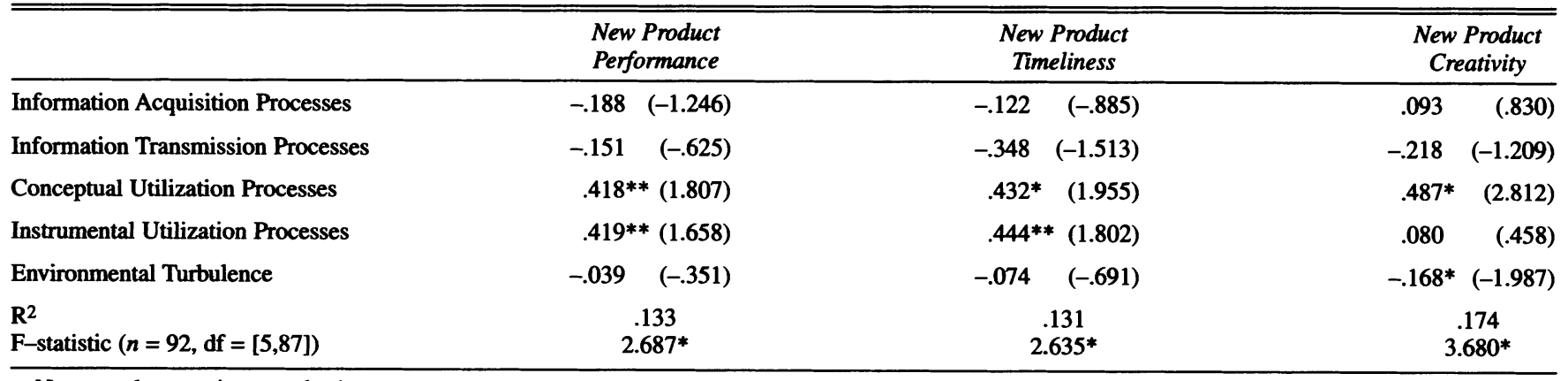

Note: $t$-values are in parenthesis.

${ }^{*} p<.05$

$* * p<.10$ 
In considering the dominance of clans, the question is raised as to why clans have the most intensive informational environment. Derived from clans' value orientation, information intensity appears to be a function of the degree to which organizations have an internal orientation and an informal structure that stresses participation, teamwork, and cohesiveness. Mohr and Nevin (1990) support this view by proposing that cultures 10 that are high in trust and mutual supportiveness foster higher levels of communication and more bidirectional information flows (i.e., upward and downward in the organization). Likewise, clans may promote a greater sense of shared identity or commitment, which increases members' cooperation (Morgan and Hunt 1994), degree of interaction (Deshpandé and Zaltman 1982), and quality of interaction (Moorman, Zaltman, and Deshpandé 1992). In summary, these results extend prior research by suggesting that organizational information processes are fundamentally "people processes" that require trust and commitment among organizational members.

The results also indicate that none of the cultures, including adhocracies, encourages information acquisition processes. These results may indicate that acquisition processes are fairly common in most organizations (Barabba and Zaltman 1991) and, therefore, that cultural antecedents are not predictive of their presence. The findings also raise the question of whether adhocracies de-emphasize traditional information processes in lieu of more improvisational decision making and implementation approaches (Moorman and Miner 1995; Weick 1993a, b). Such an assertion would be consistent with past depictions of the information processing styles of individual managers in adhocracies as "play[ing] a best hunch and then learn[ing] and adapt[ing] as you go" (Webster and Deshpandé 1990, p. 11). Finally, the results may also indicate that culture interacts with the environment to influence organizational information processes, especially in the case of information acquisition processes. Specifically, based on previous research, it might be predicted that informal cultures promote information acquisition only in turbulent environments (Achrol 1991; Glazer and Weiss 1993; Reukert, Walker, and Roering 1985).

My study finds that market cultures do not support any of the information processes as strongly as clans do. Perhaps, the markets' focus on competitive superiority and the accompanying individualistic and opportunistic orientations of individual members (Ouchi 1980) reduces the prevalence of information processes. Because prior research has indicated that organizational information processes increase performance (see Jaworski and Kohli 1993; Narver and Slater 1990), markets' inability to sustain such processes may reduce their competitiveness relative to other cultures. However, prior research has indicated that market cultures actually promote higher performance than the other three cultures (Deshpandé, Farley, and Webster 1993). The disparate results may be due to several factors. First, there are differences in the contexts in which the effects of culture were assessed. Deshpandé, Farley, and Webster's (1993) study focuses on overall business performance, whereas my study focuses on new product development performance. Thus, it

\footnotetext{
10Mohr and Nevin focus explicitly on climate as opposed to culture, but
} note that many researchers consider culture and climate to be synonymous. may be that clans are more predictive of effective organizational information processes in new product development activities, whereas markets are more predictive in less innovative, more incremental marketing activities. Second, perhaps clans achieve their effects on performance by influencing how organizations process information, whereas markets achieve performance more directly. Finally, previous research has examined the effect of culture on business performance, using "market" indicators, such as market share, profitability, growth rate, and business size relative to competitors (Deshpandé, Farley, and Webster 1993). Therefore, it is not surprising that markets have been found to be the most predictive of performance.

It does, however, remain paradoxical that clan cultures, which, by definition, are internally oriented, are also the most effective at transmitting and using "market" information. This paradox raises the interesting question about the proper balance between internal and external orientations in firms for promoting the use of market information. Day (1994) suggests that an internal focus weakens a firm's ability to learn about markets. However, my research extends his view by pointing to the importance of having sufficient internal focus to sustain information use through trust and commitment between organizational members. In further considering this balance between internal and external orientations, it should be noted that I do not adopt a methodological approach that forces cultures to be evaluated as competing, which is characteristic of work in this literature (Deshpandé, Farley, and Webster 1993; Quinn and McGrath 1985). Such an approach, which uses a summated scale asking respondents to trade off among culture types, may force a competing perspective that is not based in reality. In fact, Quinn (1988; see also Quinn and Cameron 1983) suggests that effective organizations are likely to contain all the aspects of a culture that can be evoked when certain organizational or environmental needs arise. In accordance with this view, my study allowed respondents to evaluate each culture on a 7-point Likert scale that indicated the degree to which they thought their division reflects certain characteristics. Therefore, cultures were not constrained to be competing. A correlation of $\rho=.76$ (see Table 1 ) was found between markets and clans, which indicates that though clans were the most effective users of information, clans and markets coexisted in many firms in the sample. This result indicates the importance of having an external orientation that motivates the need for information and an internal orientation that fosters its effective transmission and utilization.

Future Research Directions. Additional research could formally examine the extent to which the organizational information processes mediate the organizational culture-new product outcome relationships, as was implied in the hypotheses. Alternatively, researchers could theorize about the direct effects of culture on new product outcomes, as well as the indirect effects achieved through the organizational information processes. Examining direct and indirect effects may be particularly fruitful for investigating differences between how markets and clans achieve their influence on performance. Furthermore, it was suggested that how culture influences organizational information processes may be contingent on several factors. Therefore, further research 
may wish to adopt a moderator approach and examine, for example, the extent to which these results vary as a function of new versus incremental marketing activities. Finally, further research could compare competing and noncompeting approaches to measuring culture and determining its effects on organizational information activities.

\section{The Effects of the Organizational Market Information Processes on New Products}

It was surprising to find that information acquisition and transmission processes are not related to new product performance and timeliness in my sample. This may be because a high level of information entering and moving within an organization, especially information that is complex and ambiguous, could result in information overload (Huber and Daft 1987; Staw, Sandelands, and Dutton 1981), particularly in the absence of staff and systems for organizing and prioritizing this information. Theoretically, the results indicate that models of organizational information processing and learning should downplay the importance of acquisition and transmission processes in assessing their impact on new product outcomes. Together with past models of organizational information processes, these weak results also indicate the possibility that the effect of acquisition and transmission processes on new product outcomes is mediated by utilization processes (e.g., acquisition $\rightarrow$ transmission $\rightarrow$ utilization $\rightarrow$ new product outcomes).

The finding that new product performance is promoted by instrumental utilization processes supports the linkages that previous research has made between firms' intensifying their adoption of information processes and the effectiveness of firm outputs (Glazer 1991). Moreover, the fact that conceptual utilization processes are also predictive of new product performance contributes to the extant research that rarely measures these processes and has had limited success in detecting their effects (Rich 1981; Weiss and Bucuvalus 1980). Most important, no research in marketing has empirically assessed the value of conceptual use processes for firms. The results suggest that conceptual utilization processes do produce important bottom-line benefits for firms.

Conceptual and instrumental utilization were also found to increase the timeliness of new products. In considering these findings, I speculate that, though the utilization processes take time to enact, their effective enactment may actually result in time savings for firms. Specifically, one reason strategies are either ineffective or untimely may be due to a lack of shared vision or commitment to the direction indicated in market information (Sinkula 1994), something that conceptual use furthers within organizations. Additionally, the results point to the importance of acting on information in a decisive manner-something furthered by effective instrumental use processes.

Finally, only conceptual utilization processes positively influence new product creativity, which indicates that creativity is, in part, a function of an organization's commitment to information and the degree to which it supports deep processing of acquired information. Environmental turbulence, on the other hand, has a negative effect on creativity. Organizations seeking to generate creative strategies should, therefore, consider the challenging issue of how to buffer themselves from a turbulent environment or foster conceptual utilization processes. Moreover, further research could examine how conceptual use processes translate into creative strategies. Adopting more ethnographic approaches might illuminate the interpersonal and organizational mechanisms underlying these results (see Workman 1993).

Future Research Directions. These findings support the view that the competitive advantage associated with information depends less on whether a firm has information and increasingly on whether a firm is able to make the best use of that information (Glazer 1991; Porter and Millar 1985). However, further research should formally investigate whether the utilization processes are mediating the impact of information acquisition and transmission processes. Further research could also add to these results by examining whether the effectiveness of the information processes varies as a function of organizational size, structure, or commitment from top management (Haeckel 1990) or as a function of the characteristics of the information, such as its complexity or actionability (Deshpandé and Zaltman 1982; Menon and Varadarajan 1992). It would also be fruitful to examine whether the information processes influence mature products in the same way as new products. Finally, further research could examine the extent to which organizational culture moderates the effect of the information processes on new product outcomes by suggesting that the greater the congruence between culture and information processes, for example, adhocracies and information acquisition processes (which are both externally oriented), the greater the new product outcomes.

\section{Study Limitations}

Despite the advantages associated with the current measures of the organizational market information processes articulated previously, they could be improved on in further research. First, a subset of the measures asked informants to rate the extent to which their organizations had certain information processes in place during the projects they were evaluating. Unfortunately, the organization may not actually have been implementing these processes. However, because these measures were purified with other measures that were stated more explicitly in terms of their implementation, the measures appear to be valid. Despite these assurances, additional research should question directly the degree to which all of these processes were implemented.

Second, the organizational market information process measures failed to distinguish between formal and informal information processes. Doing so would have allowed for examining whether formal (or informal) cultures also have more formal (or informal) organizational market information processes. Further research could pursue this distinction, which would allow for investigations into whether the degree of formality in the processes influences their effectiveness, which has been suggested in prior research (Armstrong 1982; Capon, Farley, and Hulbert 1987). For example, informal transmission processes may be more effective than formal transmission processes in promoting timeliness because they allow for the quick transfer of information.

Third, single informants were used to measure the organizational information processes. Although the use of multi- 
ple informant designs remains the exception in marketing and organizational research, such an approach would clearly be a stronger test of the theory and would eliminate the concern that the results are simply picking up a giant haloeffect across the measures. ${ }^{11}$

Fourth, the marketing outcomes focused informants on products that have been in the market for a minimum of 12 months. This focus reflected discussions with executives that indicated it would be difficult to report on the performance of products in a shorter time period. However, because of the approach adopted, their reports could have been biased toward successful product introductions. Further research could overcome this limitation by also focusing on new products that lasted less than a year, but for which performance outcomes exist.

Fifth and finally, this research did not explore the direct relationship between information processes and decision making. Instead, the quality of decision making was inferred from the quality of performance. Although this is an incomplete description of the impact of information, it was chosen

11Following John and Reve's (1982) findings, the need for multiple informants is much greater in studies focusing on informants' perceptions of organizational-level sentiments (e.g., norms of exchange such as trust), which display less convergence among informants than in studies focusing on informants' perceptions of organizational structural or process variables (e.g., formalization or nature of interactions), including market information processes, which typically display more convergence. because it was unclear whether informants would be able to isolate specific decisions leading to performance outcomes.

\section{Conclusion}

Although marketing has historically addressed information processing and utilization from the perspective of the individual decision maker, my research suggests that understanding how organizations perform these activities is also a valuable perspective. Drawing on diverse literatures, I conceive of four organizational market information processes and demonstrate their distinctiveness from individual information utilization. This research went beyond a focus on structural antecedents of information use behaviors to assess the cultural antecedents of information processes in firms and find evidence that clan cultures emphasize more organizational market information processes than do markets, adhocracies, and hierarchies. Finally, my research demonstrated that information processes may act as "knowledge assets" that can be leveraged to achieve competitive advantage in new products. The most valuable of the organizational information processes were the information utilization processes: Conceptual utilization processes increased the performance, timeliness, and creativity of new products, whereas instrumental utilization processes increased the performance and timeliness of new products.

\section{Appendix}

\section{Organizational Market Information Processes ${ }^{a}$}

During this project, my division had formal or informal processes...

- Acquisition 1: for continuously collecting information from customers.

- Acquisition 2: for continuously collecting information about competitors' activities.

- Acquisition 3: for continuously collecting information about relevant publics other than customers and competitors.

- Acquisition 4: for continuously reexamining the value of information collected in previous studies.

- Acquisition 5: for continuously collecting information from external experts, such as consultants.

- Transmission 1: for sharing information effectively between marketing and other departments.

- Transmission 2: for sharing information effectively within the marketing department.

- Conceptual 1: which summarized information, reducing its complexity.

- Conceptual 2: that encouraged decision makers to disagree and to challenge one others' opinions.

- Conceptual 3: which encouraged managers to develop predictions regarding the product's success.

- Conceptual 4: for organizing information in meaningful ways.

- Conceptual 5: for processing information about the product.

- Instrumental 1: for carefully evaluating various marketing strategy alternatives.

- Instrumental 2: that relied heavily upon information to make decisions relating to the project.
- Instrumental 3: that used information to solve specific problems encountered in the project.

- Instrumental 4: that provided information to effectively implement the project.

- Instrumental 5: that provided clear direction on implementation of the project.

- Instrumental 6: that gave information to all functions regarding their role in implementation.

- Instrumental 7: that formally evaluated the effectiveness of the project.

- Instrumental 8: that provided informal feedback regarding the effectiveness of the project.

- Instrumental 9: that provided feedback to decision makers regarding the outcomes of their project decisions.

- Instrumental 10: that constructively evaluated project outcomes.

- Instrumental 11: that encouraged managers to understand the reasons for their mistakes throughout the project.

During this project, my division...

- Transmission 3: had formal information links established between all parties involved in the project.

- Transmission 4: had informal networks that ensured marketing decision makers generally had the information they needed.

- Transmission 5: employed people who were willing to educate others during the project.

- Transmission 6: took the necessary time to properly train employees in new tasks relating to this project. 
- Conceptual 6: valued information as an aid to decision making regarding the project.

- Conceptual 7: viewed new information as disruptive to the project.*

- Conceptual 8: devalued the role of information providers (e.g., marketing researchers).*

- Conceptual 9: structured jobs so that information providers played a role in strategy development.

- Instrumental 12: integrated information from a variety of sources when developing marketing strategies.

- Instrumental 13: ensured that all information sources were considered in decision making (not only those that supported the preferred action).

\section{Organizational Cultureb}

Most businesses will be some mixture of the various descriptions noted below. Indicate the degree to which these qualities reflect your division.

My division is very:

- Clan 1:

personal. It's like an extended family. People seem to share a lot of themselves.

- Adhocracy 1: dynamic and entrepreneurial. People are willing to stick their necks out and take risks.

- Market l: $\quad$ production oriented. The major concern is with getting the job done. People aren't very personally involved.

The head of my division is generally considered to be:

- Clan 2: $\quad$ a mentor, sage, or a father or a mother figure.

- Adhocracy 2: an entrepreneur, an innovator, or a risk taker.

- Hierarchy 2: a coordinator, an organizer, or an administrator.

- Market 2: a producer, a technician, or a hard-driver.

The glue that holds my division together is:

- Clan 3: loyalty and tradition. Commitment to this firm runs high.

- Adhocracy 3: a commitment to innovation and development. There is an emphasis on being first.

- Hierarchy 3: formal rules and policies. Maintaining a smooth-running institution is important here.

- Market 3: an emphasis on tasks and goal accomplishment. A production orientation is shared.

My division emphasizes:

- Clan 4: $\quad$ human resources. High cohesion and morale in the firm are important.

- Adhocracy 4: growth and acquiring new resources. Readiness to meet new challenges is important.

- Hierarchy 4: permanence and stability. Efficient, smooth operations are important.

- Market 4: $\quad$ competitive actions and achievement. Measurable goals are important.

\section{New Product Outcomes}

Rate the extent to which the product has achieved the following outcomes during the first 12 months of its life in the marketplace.

New Product Performance: a

- Market share relative to its stated objective

- Sales relative to its stated objective

- Return on assets relative to its stated objective

- Profit margin relative to its stated objective

- Return on investment relative to its stated objective

New Product Timeliness: $a$

- Timely - Untimely*

- Opportune - Inopportune*

- Well timed - Poorly timed*

New Product Creativity: a

- Very novel for this category - Very ordinary for this category*

- Challenged existing ideas for this category - Did not challenge existing ideas for this category*

- Offered new ideas to the category - Did not offer new ideas to the category*

- Creative - Not creative*

- Interesting - Uninteresting*

- Spawned ideas for other products - Did not generate ideas for other products*

- Encouraged fresh thinking - Did not encourage fresh thinking*

\section{Other Discriminating and Control Variables}

Individual Manager Use of Market Information:c

- Market information enriched my basic understanding of the project.

- The way I thought about this project would have been very different if research had not been conducted.

- I thought about available market information for a long time.

- The process of doing research really enlightened my understanding of the project.

- Market information reduced my uncertainty about the project.

- Market information helped me identify aspects of the project that would otherwise have gone unnoticed.

- My ability to make project decisions would have been diminished without research.

- My project decisions really did not require market information.

- I used market information to make specific decisions for the project.

- Without this market information, my decisions would have been very different.

Environmental Turbulence (Competitive Intensity): $d$

- Competition in this product area is cut throat.

- There are many promotion wars in this product area.

- Anything that one competitor can offer in this product areas, others can match readily.

- Price competition is a hallmark in this area.

- One hears of a new competitive move in this product area almost everyday.

- Our competitors in this product area are relatively weak.*

NOTE: With the exception of new product timeliness and creativity, which used a semantic differential scale, and new product performance, which used a 7-point Likert scale, where 1 was "low" and 7 was "high," all other constructs used a 7-point Likert scale, where 1 was "strongly disagree" and 7 was "strongly agree."

*Starred items were reverse coded.

aNew Scale.

bSource: Deshpandé, Farley, and Webster (1993).

cAdapted from Deshpandé and Zaltman (1982).

dSource: Jaworski and Kohli (1993). 


\section{REFERENCES}

$\rightarrow$ Achrol, Ravi S. (1991), "Evolution of the Marketing Organization: New Forms for Turbulent Environments," Journal of Marketing, 55 (October), 77-93.

Aguilar, Francis (1967), Scanning the Business Environment. New York: Macmillan.

AMA Task Force (1988), "Developing, Disseminating, and Utilizing Marketing Knowledge," Journal of Marketing, 52 (October), $1-25$.

$\rightarrow$ Anderson, James C. (1987), "An Approach for Confirmatory Measurement and Structural Equation Modeling of Organizational Properties," Management Science, 33 (April), 525-41.

Andrews, Jonlee (1992), "In Search of the Marketing Imagination: Factors Affecting the Creativity of Marketing Programs for Mature Products," unpublished doctoral dissertation, Graduate School of Business, University of Wisconsin, Madison.

$\rightarrow$ Armstrong, J. Scott (1982), "The Value of Formal Planing for Strategic Decisions: Review of Empirical Research," Strategic Management Journal, 3 (July/September), 197-211.

- and Terry S. Overton (1977), "Estimating Nonresponse Bias in Mail Surveys," Journal of Marketing Research, 14 (August), 396-402.

$\rightarrow$ Argyris, Chris (1976), "Single-Loop Learning and Double-Loop Models in Research on Decision-Making," Administrative Science Quarterly, 21 (September), 363-75.

- and Donald A. Schön (1978), Organizational Learning: A Theory of Action Perspective. Reading, MA: Addison-Wesley.

$\rightarrow$ Bagozzi, Richard P. and Lynn W. Phillips (1982), "Representing and Testing Organizational Theories: A Holistic Construal," Administrative Science Quarterly, 27 (September), 459-89.

Barabba, Vincent and Gerald Zaltman (1991), Hearing the Voice of the Market. Boston: Harvard Business School Press.

Bentler, Peter M. and Chih-Ping Cho (1988), "Practical Issues in Structural Modeling," in Common Problems/Proper Solutions: Avoiding Error in Quantitative Research, J. Scott Long, ed. Newbury Park, CA: Sage Publications, 161-92.

Bettman, James R. (1979), An Information Processing Theory of Consumer Choice. Reading, MA: Addison-Wesley Publishing Company.

_- Eric J. Johnson, and John W. Payne (1991), "Consumer Decision Making," in Handbook of Consumer Behavior, Thomas S. Robertson and Harold H. Kassarjian, eds. Englewood Cliffs, NJ: Prentice Hall.

$\rightarrow$ Beyer, Janice M. and Harrison M. Trice (1982), "The Utilization Process: A Conceptual Framework and Synthesis of Empirical Findings," Administrative Science Quarterly, 27 (December), 591-622.

Cameron, Kim S. and Sarah J. Freeman (1991), "Cultural Congruence, Strength, and Type: Relationships to Effectiveness," in $R e$ search in Organizational Change and Development, Vol. 5, R. W. Woodman and W. A. Passmore, eds. Greenwich, CT: JAI Press Inc., 23-58.

Capon, Noel, John U. Farley, and James M. Hulbert (1987), Corporate Strategic Planning, New York: Columbia University Press.

$\rightarrow$ Churchill, Gilbert A., Jr. (1979), "A Paradigm for Developing Better Measures of Marketing Constructs," Journal of Marketing Research, 16 (February), 64-73.

Clark, K. M. and T. Fujimoto (1991), Product Development Performance: Strategy, Organization, and Management in the World Auto Industry. Boston: Harvard Business School Press.

Cohen, Joel B., Paul W. Miniard, and Peter R. Dickson (1980), "Information Integration: An Information Processing Perspective," in Advances in Consumer Research, Vol. 7, Jerry C. Olson, ed. Ann Arbor, MI: Association for Consumer Research, 161-70.

$\rightarrow$ Cohen, Wesley M. and Daniel A. Levinthal (1990), "Absorptive
Capacity: A New Perspective on Learning and Innovation," Administrative Science Quarterly, 35 (September), 128-52.

Cooper, Robert G. and Elko J. Kleinschmidt (1994), "Determinants of Timeliness in Product Development," Journal of Product Innovation Management, 11 (December), 381-96.

Cyert, Richard M. and James G. March (1992), A Behavioral Theory of the Firm, 2nd ed. Oxford: Blackwell.

$\rightarrow$ Daft, Richard L. and Karl E. Weick (1984), "Toward a Model of Organizations as Interpretation Systems," Academy of Management Review, 9 (April), 284-95.

Day, George S. (1991), "Learning About Markets," Marketing Science Institute, Report No. 91-117. Cambridge, MA: Marketing Science Institute.

(1994), "The Capabilities of Market-Driven Organizations," Journal of Marketing, 58 (October), 37-52.

_ and Prakash Nedungadi (1994), "Managerial Representations of Competitive Advantage," Journal of Marketing, 58 (April), 31-44.

Deal, T. E. and A. A. Kennedy (1982), Corporate Cultures: The Rights and Rituals of Corporate Life. Reading, MA: AddisonWesley.

Denison, Daniel R. and Gretchen M. Spreitzer (1991), "Organizational Culture and Organizational Development: A Competing Values Approach," in Research in Organizational Change and Development, Vol. 5, Richard W. Woodman and William A. Passmore, eds. Greenwich, CT: JAI Press, Inc., 1-21.

Deshpandé, Rohit (1982), "The Organizational Context of Market Research Use," Journal of Marketing, 46 (Fall), 91-101.

and Gerald Zaltman (1982), "Factors Affecting the Use of Market Research Information: A Path Analysis," Journal of Marketing Research, 19 (February), 14-31.

and - (1984), "A Comparison of Factors Affecting Researcher and Manager Perceptions of Market Research Use," Journal of Marketing Research, 21 (February), 32-38. and Ajay Kohli (1989), "Knowledge Disavowal: Structural Determinants of Information-Processing Breakdown in Organizations," Knowledge: Creation, Diffusion, and Utilization, 11 (December), 155-169.

- and Frederick E. Webster, Jr. (1989), “Organizational Culture and Marketing: Defining the Research Agenda," Journal of Marketing, 53 (January), 3-15.

- John U. Farley, and Frederick E. Webster, Jr. (1993), "Corporate Culture, Customer Orientation, and Innovativeness in Japanese Firms: A Quadrad Analysis," Journal of Marketing, 52 (January), 23-36.

$\rightarrow$ Dickson, Peter R. (1992), "Toward a General Theory of Competitive Rationality," Journal of Marketing, 56 (January), 69-83.

(1994), Marketing Management. Fort Worth, TX: The Dryden Press.

Doughterty, Deborah (1989), "Interpretive Barriers to Successful Product Innovation in Large Firms," Marketing Science Institute, Report No. 89-114. Cambridge, MA: Marketing Science Institute.

Draper, Norman R. and Harry Smith (1981), Applied Regression Analysis, 2nd ed. New York: John Wiley \& Sons, Inc.

Dunn, William N. and Ari Ginsberg (1986), "A Sociocognitive Network Approach to Organizational Analysis," Human Relations, 40 (November), 955-76.

Durkheim, Emile (1895, 1938), The Rules of Sociological Method. New York: The Free Press.

$\rightarrow$ Dutton, Jane E. and Susan E. Jackson (1987), "Categorizing Strategic Issues: Links to Organizational Actions," Academy of Management Review, 12 (January), 76-90.

$\rightarrow$ Eisenhardt, Kathleen M. (1989), "Making Fast Strategic Decisions in High-Velocity Environments," Academy of Management Journal, 32 (September), 543-76.

Fahey, Liam and K. Naraynan (1986), Macroenvironmental Analy- 
sis for Strategic Analysis. St. Paul, MN: West Publishing Company.

Fiol, C. Marlene and Marjorie A. Lyles (1985), "Organizational Learning," Academy of Management Review, 19 (October), 803-13.

$\rightarrow$ Gerbing, David W. and James C. Anderson (1988), “An Updated Paradigm for Scale Development Incorporating Unidimensionality and Its Assessment," Journal of Marketing Research, 25 (May), 186-92.

Glaser, Edward M., Harold H. Abelson, and Kathalee N. Garrison (1983), Putting Knowledge to Use: Facilitating the Diffusion of Knowledge and the Implementation of Planned Change. San Francisco, CA: Jossey-Bass Publishers.

$\rightarrow$ Glazer, Rashi (1991), "Marketing in an Information-Intensive Environment: Strategic Implications of Knowledge as an Asset," Journal of Marketing, 55 (October), 1-19.

$\rightarrow \longrightarrow$, Joel Steckel, and Russell Winer (1992), "Locally Rational Decision Making: The Distracting Effect of Information on Managerial Performance," Management Science, 38 (February), 212-26.

$\rightarrow-$ and Allen M. Weiss (1993), "Marketing in Turbulent Environments: Decision Processes and the Time-Sensitivity of Information," Journal of Marketing Research, 30 (November), 509-21.

Griffin, Abbie and John R. Hauser (1992), "Patterns of Communication Among Marketing, Engineering, and Manufacturing-A Comparison Between Two New Product Teams," Management Science, 38 (March), 360-73.

Haeckel, Stephen H. (1990), "Business Strategies in an Information Economy," Marketing Science Institute Commentary, Report Number 90-119, Cambridge, MA: Marketing Science Institute.

$\rightarrow$ Hatch, Mary Jo (1993), "The Dynamics of Organizational Culture," Academy of Management Review, 18 (October), 657-93.

Hedberg, Bo (1981), "How Organizations Learn and Unlearn," in Handbook of Organizational Design, P. C. Nystram and W. H. Starbuck, eds. London: Oxford University Press, 3-27.

Holzner, B. and J. Marx (1979), Knowledge Application: The Knowledge System in Society. Boston: Allyn \& Bacon.

Houston, Mark B. (1993), "A Cognitive Perspective of Group Interaction and Marketing Strategy Formulation," in Marketing Theory \& Applications, AMA Winter Educators' Proceedings, R. Varadarajan and B. Jaworski, eds. Chicago: American Marketing Association, 3-11.

$\rightarrow$ Huber, George P. (1991), "Organizational Learning: The Contributing Processes and the Literatures," Organizational Science, 2 (February), 88-115.

2 and Richard Daft (1987), "The Information Environment of Organizations," in Handbook of Organizational Communications: An Interdisciplinary Perspective, F. Jablin, Linda L. Putnam, Karlene H. Roberts, and Lyman W. Porter, eds. Newbury Park, CA: Sage Publications, 389-419.

$\rightarrow$ Hutt, Michael D., Peter H. Reingen, and John R. Ronchetto, Jr. (1988), "Tracing Emergent Processes in Marketing Strategy Formation," Journal of Marketing, 52 (January), 4-19.

Imai, K., I. Nonaka, and H. Takeuchi, (1985), "Managing the New Product Development Process: How Japanese Firms Learn and Unlearn," in The Uneasy Alliance, K. Clark, R. Hayes, and C. Lorenz, eds. Boston: Harvard Business School, 337-75.

$\rightarrow$ Jackson, Susan E. and Jane E. Dutton (1988), "Discerning Threats and Opportunities," Administrative Science Quarterly, 33 (September), 370-87.

$\rightarrow$ Jaworski, Bernard J. and Ajay K. Kohli (1993), "Market Orientation: Antecedents and Consequences," Journal of Marketing, 57 (July), 53-71.

John, George and Torger Reve (1982), "The Reliability and Validity of Key Informant Data from Dyadic Relationships in Mar- keting Channels," Journal of Marketing Research, 19 (November), 517-24.

$\rightarrow \longrightarrow$ and John Martin (1984), "Effects of Organizational Structure of Marketing Planning on Credibility and Utilization of Plan Output," Journal of Marketing Research, 21 (March), $170-83$.

Jöreskog, Karl G. and Dag Sorbom (1989), LISREL 7: A Guide to the Program and Applications, 2nd ed. Chicago: SPSS, Inc.

Kahneman, Daniel (1973), Attention and Effort. Englewood Cliffs, NJ: Prentice Hall.

Kiesler, Sara and Lee Sproull (1982), "Managerial Response to Changing Environments: Perspective on Problem Sensing from Social Cognition," Administrative Science Quarterly, 27 (December), 548-70.

Klein, Harold E. and William H. Newman (1980), "How to Integrate Environmental Forces into Strategic Planning," Management Review, 69 (July), 40-48.

Knorr-Cetina, Karin (1981), The Manufacture of Knowledge. Oxford: Pergaman Press.

$\rightarrow$ Kohli, Ajay K. and Bernard J. Jaworski (1990), "Market Orientation: The Construct, Research Propositions, and Managerial Implications," Journal of Marketing, 54 (April), 1-18.

$\rightarrow \longrightarrow,-\longrightarrow$, and Ajith Kumar (1993), "MARKOR: A Measure of Market Orientation," Journal of Marketing Research, 30 (November), 467-77.

$\rightarrow$ Lavidge, Robert J. and Gary A. Steiner (1961), "A Model for Predictive Measures of Advertising Effectiveness," Journal of Marketing, 25 (October), 59-62.

Leonard-Barton, Dorothy (1991), "Core Capabilities and Core Rigidities: A Paradox in Managing New Product Development," Strategic Management Journal, 13 (Summer), 111-25.

$\rightarrow-$ and I. DeSchamps (1988), "Managerial Influence in the Implementation of New Technology," Management Science, 34 (October), 1252-65.

$\rightarrow$ Levitt, Barbara and James G. March (1988), "Organizational Learning," Annual Review of Sociology, 14, 319-40.

Levitt, Theodore (1960), "Marketing Myopia," Harvard Business Review, 38 (July/August), 45-56.

Lovell, Rickie D. and Billy M. Turner (1988), "Organizational Learning, Bureaucratic Control, Preservation of Form: Adding to Our Basic Understanding of Research Utilization in Public Organizations," Knowledge: Creation, Diffusion, Utilization, 9 (March), 404-25.

Mahajan, Jayashree (1992), "The Overconfidence Effect in Marketing Management Predictions," Journal of Marketing Research, 24 (August), 329-42.

Marketing Science Institute (1994), Research Priorities 1994-1996. Cambridge, MA: Marketing Science Institute.

Mason, Charlotte H. and William D. Perreault, Jr. (1991), "Collinearity, Power, and Interpretation of Multiple Regression," Journal of Marketing Research, 28 (August), 268-80.

$\rightarrow$ Menon, Anil and P. Rajan Varadarajan (1992), "A Model of Marketing Knowledge Use Within Firms," Journal of Marketing, 56 (October), 53-71.

Mintzberg, Henry (1979), The Structuring of Organizations: A Synthesis of the Research. Englewood Cliff, NJ: Prentice Hall.

_ Duru Raisinghani, and Andre Theoret (1976), "The Structure of Unstructured Decision Process," Administrative Science Quarterly, 21 (June), 246-75.

$\rightarrow$ Mohr, Jakki and John R. Nevin (1990), "Communication Strategies in Marketing Channels," Journal of Marketing, 54 (October), 36-51.

$\rightarrow$ Moorman, Christine, Gerald Zaltman, and Rohit Deshpandé (1992), "Relationships Between Providers and Users of Market Research: The Dynamics of Trust Within and Between Organizations," Journal of Marketing Research, 29 (August), 314-29.

$\rightarrow \longrightarrow$, Rohit Deshpandé, and Gerald Zaltman (1993), "Factors 
Affecting Trust in Market Research Relationships," Journal of Marketing, 57 (January) 81-101.

- and Anne S. Miner (1995), "Walking the Tightrope: Improvisation in New Product Development and Introduction," Marketing Science Institute, Report No. 95-101. Cambridge, MA: Marketing Science Institute.

$\rightarrow$ Morgan, Robert M. and Shelby D. Hunt (1994), "The Commitment-Trust Theory of Relationship Marketing," Journal of Marketing, 58 (July), 20-38.

Nadler, D. A. and M. L. Tushman (1980), "A Congruence Model for Organizational Assessment," in Organizational Assessment: Perspectives of Organizational Behavior and the Quality of Working Life, E. E. Lawler, D. A. Nadler, and C. Camman, eds. New York: John Wiley \& Sons, Inc.

$\rightarrow$ Narver, John C. and Stanley F. Slater (1990), "The Effect of a Market Orientation on Business Profitability," Journal of Marketing, 54 (October), 20-35.

$\rightarrow$ Nelson, Richard R. (1982), "The Role of Knowledge in R\&D Efficiency," The Quarterly Journal of Economics, 97 (August), 453-70.

Neter, John and William Wasserman (1974), Applied Linear Statistical Models. Homewood, IL: Richard D. Irwin, Inc.

Nonaka, Ikujiro (1990), "Redundant Overlapping Organization: A Japanese Approach to Managing the Innovation Process," California Management Review, 32 (Spring), 27-38.

$\rightarrow$ Nutt, Paul (1986), "Tactics of Implementation," Academy of Management Journal, 29 (April), 230-61.

Olson, Jerry C. (1978), "Theories of Information Encoding and Storage: Implications for Consumer Behavior," in The Effect of Information on Consumer and Market Behavior, Andrew A. Mitchell, ed. Chicago: American Marketing Association, 49-60.

$\rightarrow$ Ouchi, William G. (1980), "Markets, Bureaucracies, and Clans," Administrative Science Quarterly, 25 (March), 129-41.

Patton, M. (1978), Utilization-Focused Evaluation. Beverly Hills, CA: Sage Publications, Inc.

Pedhazur, Elazar J. (1982), Multiple Regression in Behavioral Research: Explanation and Prediction. New York: Holt, Rinehart and Winston, Inc.

$\rightarrow$ Perkins, W. Steven and Ram C. Rao (1990), "The Role of Experience in Information Use and Decision Making by Marketing Managers," Journal of Marketing Research, 27 (February), $1-10$.

Porter, Michael and Victor E. Millar (1985), "How Information Gives You Competitive Advantage," Harvard Business Review, 85 (July/August), 149-60.

Quinn, Robert E. (1988), Beyond Rational Management. San Francisco, CA: Jossey-Bass Publishers.

and Kim S. Cameron (1983), "Organizational Life Cycles and Shifting Criteria of Effectiveness: Some Preliminary Evidence," Management Science, 29 (January), 33-51.

and J. Rohrbaugh (1983), "A Spatial Model of Effectiveness Criteria: Toward a Competing Values Approach to Organizational Analysis," Management Science, 29 (3), 363-77.

and Michael R. McGrath (1985), "Moving Beyond the Single-Solution Perspective: The Competing Values Approach as a Diagnostic Tool," Journal of Applied Behavioral Science, 18 (4), 463-72.

- and Gretchen M. Spreitzer (1991), "The Psychometrics of the Competing Values Culture Instrument and an Analysis of the Impact of Organizational Culture on Quality of Life," in Research in Organizational Change and Development, Vol. 5, Richard W. Woodman and William A. Passmore, eds. Greenwich, CT: JAI Press, Inc., 115-42.

Ray, Michael L., Alan G. Sawyer, Michael L. Rothschild, Roger M. Heeler, and Jerome C. Strong (1973), "Marketing Communication and the Hierarchy of Effects," in New Models for Communication Research, P. Clark, ed. Beverly Hills, CA: Sage Publi- cations, Inc., 147-76.

Rich, Robert F. (1981), Social Science Information and Public Policy Making. San Francisco, CA: Jossey-Bass Publishers.

Rogers, Everett M. (1983), Diffusion of Innovations. New York: The Free Press.

$\rightarrow$ Ruekert, Robert W., Orville C. Walker, Jr., and Kenneth J. Roering (1985), "The Organization of Marketing Activities: A Contingency Theory of Structure and Performance," Journal of Marketing, 49 (Winter), 13-25.

Sandelands, Lloyd E. and Ralph E. Stablein (1987), "The Concept of Organization Mind," in Research in the Sociology of Organizations, Vol. 5, Samuel B. Bacharach, ed. Greenwich, CT: JAI Press, Inc., 135-61.

Senge, Peter M. (1990), The Fifth Discipline: The Art and Practice of the Learning Organization. New York: Doubleday.

$\rightarrow$ Sinkula, James M. (1994), "Market Information Processing and Organizational Learning," Journal of Marketing, 58 (January), $35-45$.

Slater, Stanley F. and John C. Narver (1994), "Market Oriented Isn't Enough: Build a Learning Organization," Marketing Science Institute, Report No. 94-103. Cambridge, MA: Marketing Science Institute.

Slevin, Dennis P. and Jeffrey K. Pinto (1987), "Balancing Strategy and Tactics in Project Implementation," Sloan Management Review, 33 (Fall), 33-42.

Starbuck, William H. (1976), "Organizations and their Environments," in Handbook of Industrial and Organizational Psychology, M. D. Dunnette, ed. New York: Rand McNally, 1069-1123.

Staw, Barry M., Lance E. Sandelands, and Jane E. Dutton (1981), "Threat-Rigidity Effects in Organizational Behavior," Administrative Science Quarterly, 26 (December), 501-24.

Tabrizi, Behnam N. and Kathleen M. Eisenhardt (1994), "Accelerating Product Development" working paper, Departments of Industrial Engineering and Engineering Management, Stanford University.

Thomas, James B., Shawn M. Clark, and Dennis A. Gioia (1993), "Strategic Sensemaking and Organizational Performance: Linkages Among Scanning, Interpretation, Action, and Outcomes," Academy of Management Journal, 36 (April), 239-70.

Walsh, James P. (1989), "Knowledge Structures and the Management of Organizations: A Research Review and Agenda," working paper, Tuck School, Dartmouth College.

Webster, Frederick E., Jr. and Rohit Deshpandé (1990), "Analyzing Corporate Cultures in Approaching the Global Marketplace," Marketing Science Institute, Report No. 90-111. Cambridge, MA: Marketing Science Institute.

Weick, Karl E. (1969), The Social Psychology of Organizing. Reading, MA: Addison-Wesley.

- (1979), "Cognitive Processes in Organizations," in $\mathbf{R e}$ search in Organizational Behavior, Vol. 1, Barry N. Staw, ed. Greenwich, CT: JAI Press, 41-74.

- (1993a), "The Collapse of Sensemaking in Organizations: The Mann Gulch Disaster," Administrative Science Quarterly, 38 (December), 628-52.

(1993b), "Organizational Redesign as Improvisiation," in Organizational Change \& Redesign, Geroge P. Huber and William H. Glick, eds. Oxford: Oxford University Press, 346-79.

$\rightarrow$ Weiss, Allen M. and Jan B. Heide (1993), "The Nature of Organizational Search in High Technology Markets," Journal of Marketing Research, 30 (May), 220-33.

Weiss, Carol (1978), Using Social Research in Public Policy Making. Lexington, MA: Lexington Books.

and Michael J. Bucuvalus (1980), "Truth Tests and Quality Tests," American Sociological Review, 45 (April), 303-12.

$\rightarrow$ Wilton, Peter C. and John G. Meyers (1986), "Task, Expectancy, and Information Assessment Effects in Information Utilization 
Processes," Journal of Consumer Research, 12 (March), 469-86. $\rightarrow$ Williamson, Oliver E. (1981), "The Economics of Organization: The Transaction Cost Approach," American Journal of Sociology, 87 (3), 548-77.

and William G. Ouchi (1981), "The Markets and Hierarchies and Visible Hand Perspectives," in Perspectives on Organizational Design and Behavior, Andrew H. Van de Ven and William F. Joyce, eds. New York: John Wiley \& Sons, Inc., 347-70.

Winter, Sidney G. (1987), "Knowledge and Competence as Strategic Assets," in The Competitive Challenge: Strategies for Industrial Innovation and Renewal, David J. Teece, ed. New York: Harper \& Row, 159-84.

$\rightarrow$ Workman, John P., Jr. (1993), "Marketing's Limited Role in New Product Development in One Computer Systems Firm," Journal of Marketing Research, 30 (November), 405-21.
Zaltman, Gerald (1979), "Knowledge Utilization as Planned Social Change," Knowledge: Creation, Diffusion, and Utilization, 1 (September), 82-105.

, Robert Duncan, and Jonny Holbek (1973), Innovations and Organizations. New York: John Wiley \& Sons, Inc.

, Michael Heffring, and Karen LeMasters (1983), Theory Construction in Marketing: Some Thoughts on Thinking. New York: John Wiley \& Sons, Inc.

and Christine Moorman (1989), "The Management and Use of Advertising Research," Journal of Advertising Research, 29 (6), 11-18.

Zammuto, Raymond F. and Jack Y. Krakower (1991), "Quantitative and Qualitative Studies of Organizational Culture," in Research in Organizational Change and Development, Vol. 5, Richard W. Woodman and William A. Passmore, eds. Greenwich, CT: JAI Press, Inc., 83-114.

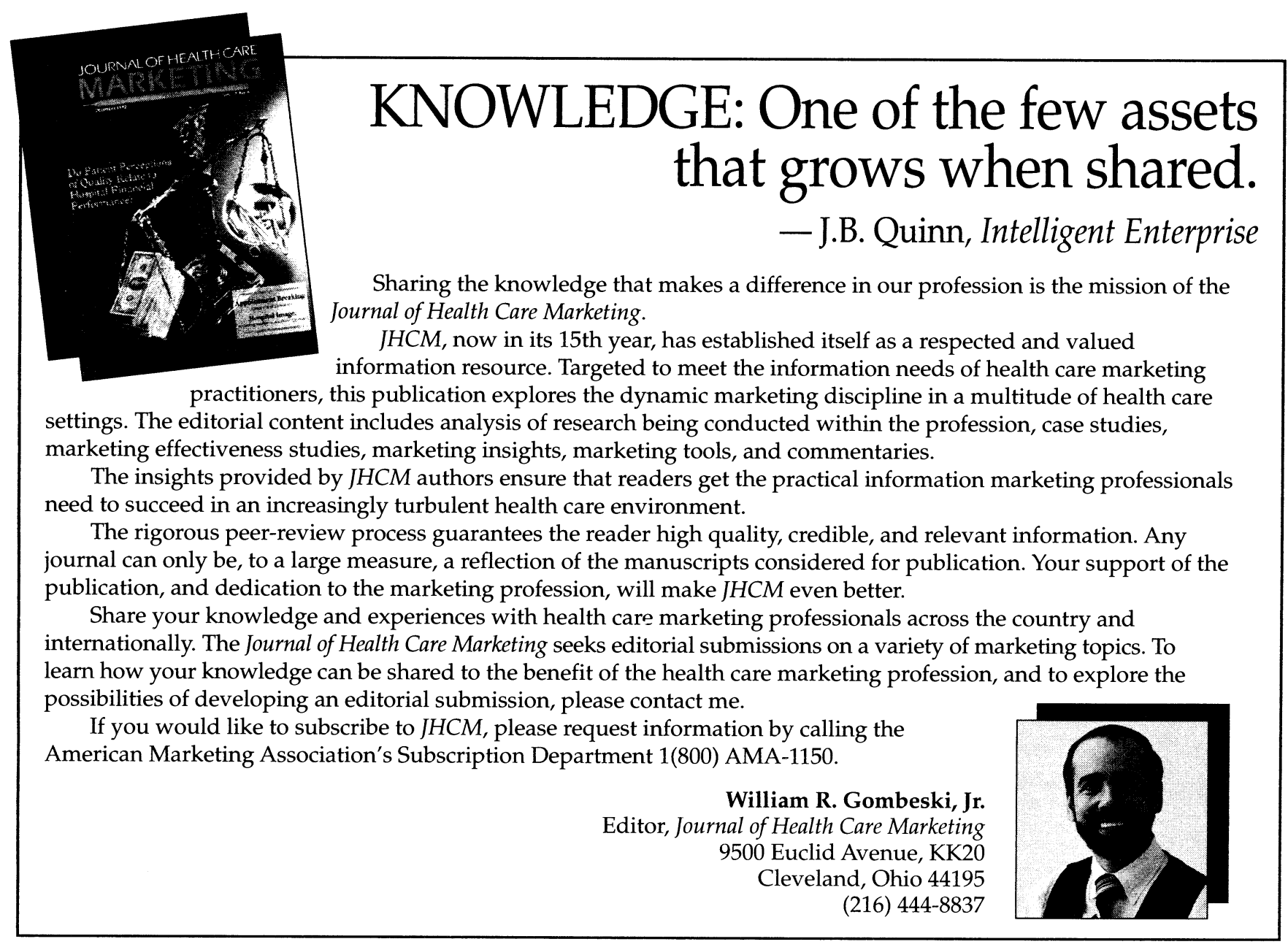

